\title{
Different Modulatory Effects of IL-17, IL-22, and IL-23 on Osteoblast Differentiation
}

\author{
Jing-Ru Zhang, ${ }^{1,2}$ Dan-Dan Pang, ${ }^{1}$ Qiang Tong, ${ }^{3}$ Xia Liu, ${ }^{4}$ Ding-Feng Su, ${ }^{4}$ and \\ Sheng-Ming $\mathrm{Dai}^{3}$ \\ ${ }^{1}$ Department of Rheumatology \& Immunology, Changhai Hospital, Second Military Medical University, Shanghai, China \\ ${ }^{2}$ Department of Rheumatology \& Immunology, The First Affiliated Hospital of Zhejiang Chinese Medical University, Zhejiang, China \\ ${ }^{3}$ Department of Rheumatology \& Immunology, Shanghai Jiao Tong University Affiliated Sixth People's Hospital, Shanghai, China \\ ${ }^{4}$ Department of Pharmacology, School of Pharmacy, Second Military Medical University, Shanghai, China
}

Correspondence should be addressed to Sheng-Ming Dai; dsm@medmail.com.cn

Received 21 January 2017; Accepted 4 June 2017; Published 27 July 2017

Academic Editor: Koen Venken

Copyright ( 92017 Jing-Ru Zhang et al. This is an open access article distributed under the Creative Commons Attribution License, which permits unrestricted use, distribution, and reproduction in any medium, provided the original work is properly cited.

Objectives. To examine the expressions of IL-17, IL-22, and IL-23 receptors in four osteoblast models and the effects of IL-17, IL-22, and IL-23 on osteoblasts. Methods. Gene expression levels of receptors, alkaline phosphatase (ALP), osteocalcin (OCN), and Runt-related transcription factor 2 (Runx-2), were evaluated by RT-PCR and real-time RT-PCR. Proliferative responses and cell cycle analysis were detected by a CCK-8 assay and flow cytometry, respectively. ALP activity and ALP mass were detected by an ALP activity assay and ALP staining, respectively. Results. In primary osteoblasts, only the IL-17 receptor was expressed. In C2C12, MC3T3-E1, and Saos-2 cells, the genes of IL-17, IL-22, and IL-23 receptors were not detectable. None of IL-17, IL-22, and IL-23 had an obvious effect on the proliferation of primary osteoblasts, but IL-17 exhibited an inhibitory effect on the gene expression of ALP, OCN, and Runx-2. The ALP activity and ALP mass of primary osteoblasts were downregulated by IL-17 treatment in a dose-dependent manner, and IL-17 failed to inhibit BMP-2-induced phosphorylation of Smad. Conclusion. Primary osteoblasts constitutively express IL-17 receptors, but none of C2C12 cells, MC3T3-E1 cells, and Saos-2 cells express any receptors for IL-17, IL-22, and IL-23. IL-17 inhibits BMP-2-induced osteoblast differentiation via the $\mathrm{BMP} / \mathrm{Smad}$-independent pathway.

\section{Introduction}

Ankylosing spondylitis (AS) is a chronic inflammatory joint disease that chiefly affects the sacroiliac joints and the spine [1]. Radiographs reveal erosive changes at the corners of the vertebral bodies in the early stages of the disease and outgrowth of bony spurs known as syndesmophytes in the later stages [2]. When these syndesmophytes make the adjacent vertebral bodies fuse together, the spine appears as a single piece and is aptly described as a bamboo spine. The pathogenesis of syndesmophyte formation in AS remains unknown.

IL-23 is an immunomodulatory cytokine; the effects of which are mediated by downstream cytokines such as IL-17 and IL-22. Recently, accumulating data suggest that the IL-23/IL-17 axis plays a pivotal role in AS. One of the earliest discoveries that implicated IL-23 signaling in AS was an association with variants in the gene encoding one subunit of the IL-23 receptor (IL-23R) [3], and the association between the IL-23 receptor and AS was confirmed in subsequent studies of individuals of European descent [4] and Chinese population [5]. Subsequently, elevated IL-17 levels were found in the serum and synovial fluid of patients with active AS, undifferentiated spondyloarthropathy (SpA), and psoriatic arthritis (PsA) [6, 7]. Also, increased numbers of IL-23-responsive T cells (including Th17 cells, ROR $\gamma \mathrm{t}+$ CD3+CD4-CD8- T cells, TCR $\gamma \delta 17$ cells, KIR3DL2+CD4+ $\mathrm{T}$ cells, and iNKT17 cells) in the peripheral blood and synovial fluid of both patients with seronegative SpA and AS were found [8-13]. Moreover, higher expression of IL-23p19 mRNA in peripheral blood mononuclear cells (PBMC) of AS patients as well as enhanced production of IL-17 in the 
supernatants of PBMC stimulated by recombinant IL-23 was found [14]. These results have been confirmed by studies with animal models of SpA in which the number of Th17 cells and the levels of IL-23, IL-17, and IL-22 were systemically or locally elevated $[13,15-17]$. Recently, the satisfactory efficacy of the anti-IL-17A monoclonal antibody secukinumab in treating patients with active AS also firmly implicates the involvement of IL-17 in the pathogenesis of AS [18]. The striking convergence of the evidences from clinical studies, genetic studies, animal models, and therapeutic trials strongly implicates that the IL-23/IL-17 axis plays a pivotal role in the pathogenesis of AS.

In addition, the possible role of the IL-23/IL-17 axis in the regulation of bone homeostasis is gradually being recognized. Some studies imply that IL-17 and IL-23 might regulate bone remodeling. For example, IL-17A promoted the production of RANKL by osteoblasts and synoviocytes and upregulated the expression of RANK on osteoclast precursors [19-22]. Moreover, it was recently reported that IL-23 stimulates the formation of functional osteoclasts in human PBMC cultures and the expression of RANK in mouse osteoclast progenitor cells [23, 24]. Langrish et al. [25] observed that lipopolysaccharide- (LPS-) driven osteoclast formation in vivo was reduced in the absence of IL-23. These data suggest the involvement of the IL-23/IL-17 axis in the regulation of bone homeostasis by inducing bone erosion in AS. Furthermore, new bone formation was found in the mice with overexpression of IL-23 [13]. However, the direct effects of the IL-23/IL-17 axis on osteoblasts or new bone formation of AS remain unknown.

In the present study, we aim to explore the possible effects of IL-17, IL-22, and IL-23 on osteoblasts. We first examined the expression levels of IL-17, IL-22, and IL-23 receptors in primary osteoblasts as well as in three representative osteoblast-like cell lines (C2C12, Saos-2, and MC3T3-E1). Furthermore, we detected the possible effects of IL-17, IL22 , and IL-23 on the proliferation and differentiation of osteoblasts. These studies will contribute to better understanding of the role of IL-17, IL-22, and IL-23 in the process of new bone formation. Based on these results, we look forward to making some advance in clarifying the role of the IL-17/IL23 axis in the physiopathology of AS.

\section{Materials and Methods}

2.1. Reagents. Recombinant human bone morphogenetic protein-2 (BMP-2) was purchased from PeproTech Inc. (Minneapolis, MN, USA). Recombinant murine IL-17A, IL22, and IL-23 were purchased from PeproTech Inc. (Rocky Hill, NJ, USA).

2.2. Cell Culture and Treatment. The mouse myoblast cell line $\mathrm{C} 2 \mathrm{C} 12$, the murine preosteoblast cell line MC3T3-E1 subclone 14, and the human osteosarcoma cell line Saos2 were purchased from Chinese Academy of Sciences (Shanghai, China). C2C12 cells were maintained in Dulbecco's modified Eagle's medium (DMEM) (Gibco, Grand Island, NY, USA) containing 15\% fetal bovine serum (FBS) (Gibco, Grand Island, NY, USA) and antibiotics
(100 U/ml of penicillin $\mathrm{G}$ and $100 \mu \mathrm{g} / \mathrm{ml}$ of streptomycin) at $37^{\circ} \mathrm{C}$ in a humidified atmosphere of $5 \% \mathrm{CO}_{2}$ in air. MC3T3-E1 cells were cultured in $\alpha$-modified Eagle's medium ( $\alpha$-MEM) (Gibco, Grand Island, NY, USA) supplemented with $10 \%$ FBS and antibiotics $(100 \mathrm{U} / \mathrm{ml}$ of penicillin $\mathrm{G}$ and $100 \mu \mathrm{g} / \mathrm{ml}$ of streptomycin) at $37^{\circ} \mathrm{C}$ in a humidified atmosphere of $5 \% \mathrm{CO}_{2}$ in air. Saos- 2 cells were maintained in DMEM containing $10 \%$ FBS and antibiotics $(100 \mathrm{U} / \mathrm{ml}$ of penicillin $\mathrm{G}$ and $100 \mu \mathrm{g} / \mathrm{ml}$ of streptomycin) at $37^{\circ} \mathrm{C}$ in a humidified atmosphere of $5 \% \mathrm{CO}_{2}$ in air. Primary rat calvarial osteoblasts were isolated from the calvaria of neonatal Sprague-Dawly rats (Animal Experimental Center of Second Military Medical University, Shanghai, China) by sequential collagenase digestion as described previously [26]. All animal experiments were undertaken in accordance with the National Institute of Health's “Guide for the Care and Use of Laboratory Animals", with the approval of the Scientific Investigation Board of Second Military Medical University.

2.3. Induction of Osteoblast Differentiation. To induce osteoblast differentiation, MC3T3-E1, Saos-2, and primary calvarial osteoblasts were seeded $\left(1 \times 10^{6}\right.$ cells $\left./ \mathrm{ml}\right)$, and after $24 \mathrm{~h}$ incubation, rhBMP-2 at the final concentration of $300 \mathrm{ng} /$ $\mathrm{ml}$ was added to the culture medium with $10 \%$ FBS. C2C12 cells were seeded $\left(1 \times 10^{6}\right.$ cells $\left./ \mathrm{ml}\right)$, and after $24 \mathrm{~h}$ incubation, the culture medium was replaced by DMEM supplemented with $5 \% \mathrm{FBS}$ and $300 \mathrm{ng} / \mathrm{ml} \mathrm{rhBMP}-2$. All of the cells were maintained at $37^{\circ} \mathrm{C}$ in a humidified atmosphere of $5 \% \mathrm{CO}_{2}$ in air, and the medium was replaced every 2 days.

2.4. Cell Proliferation Assay (CCK-8). Cell proliferation was measured as previously described, using Cell Counting Kit8 (CCK-8) according to the instruction of the manufacturer (Dojindo Laboratories, Kumamoto, Japan) [27]. Briefly, primary calvarial osteoblasts were seeded into 96-well plates $\left(5 \times 10^{3}\right.$ cells/well). After $24 \mathrm{~h}$ incubation, the culture medium was refreshed and the cultivation was continued for $24-72 \mathrm{~h}$ in the presence of IL-17 $(25 \mathrm{ng} / \mathrm{ml})$, IL-22 $(25 \mathrm{ng} / \mathrm{ml})$, and IL-23 $(25 \mathrm{ng} / \mathrm{ml})$. After the incubation for 24-72 h, the supernatant was removed and $100 \mu \mathrm{l} \mathrm{CCK-8}$ solution was added to cells. After $4 \mathrm{~h}$ of incubation with CCK-8 at $37^{\circ} \mathrm{C}$, absorbance was measured on an ELISA reader (Emax Science Corp., Sunnyvale, California, USA) at a wavelength of $450 \mathrm{~nm}$.

2.5. Cell Cycle Analysis. Cell cycle profiles were analyzed as previously described [28]. Cells were seeded at $2 \times 10^{6}$ cells per well in a 6-well plate and incubated for $24 \mathrm{~h}$. Fresh medium containing IL-17 $(25 \mathrm{ng} / \mathrm{ml})$, IL-22 $(25 \mathrm{ng} / \mathrm{ml})$, or IL-23 $(25 \mathrm{ng} / \mathrm{ml})$ was added to the culture plate. After $24 \mathrm{~h}$, the cells were collected, gently resuspended into a single cell suspension in phosphate-buffered saline (PBS), and fixed overnight with $70 \%$ ice-cold ethanol at $4^{\circ} \mathrm{C}$. Cell pellets were harvested, then resuspended in $100 \mu \mathrm{l}$ RNase A solution, and incubated for 30 minutes at $37^{\circ} \mathrm{C}$ in a water bath. Then, $400 \mu \mathrm{l}$ propidium iodide (PI) staining solution was added, and the cells were incubated in the condition protected from light for another $30 \mathrm{~min}$ at $4^{\circ} \mathrm{C}$. The percentage of cells in each of the S, G1, and G2/M phases of the cell cycle was 
determined by flow cytometry using the EPICS profile analyzer (Coulter Corp., Miami, FL, USA). The distribution in each phase of the cell cycle was determined using the ModFit LT 2.0 program, and the results were displayed as histograms.

2.6. Reverse Transcriptase Polymerase Chain Reaction (RT$P C R$ ) and Quantitative Real-Time PCR. Total RNA was extracted from C2C12, MC3T3-E1, Saos-2, and primary calvarial osteoblasts by acid guanidine-phenol-chloroform extraction using the TRIzol Reagent (Invitrogen, California, USA). RNA was evaluated spectrophotometrically for quantity and purity. First-strand complementary DNA (cDNA) was synthesized from isolated RNA using PrimeScript ${ }^{\mathrm{TM}}$ RT Master Mix (Takara, Otsu, Japan) according to the manufacturer's protocol and used as templates for PCR. PCR amplification was performed using specific primers (Supplementary Table 1 available online at https://doi.org/10.1155/2017/ 5950395). The constitutively expressed gene encoding GAPDH was used as an internal control in RT-PCR to normalize the amounts of mRNA in each sample. The PCR products were analyzed by electrophoresis in $2 \%$ agarose gels stained with ethidium bromide, and bands were visualised and photographed under ultraviolet excitation. Quantitative real-time RT-PCR was performed on the 7500 Real-Time PCR System (Applied Biosystems, Foster City, CA, USA) using FastStart Universal SYBR Green Master (Roche, Germany). Data were adjusted by the levels of GAPDH expression in each sample.

2.7. Alkaline Phosphatase (ALP) Activity. After removing the culture medium, the cell layers were washed twice with PBS and lysed in $500 \mu \mathrm{l}$ of Tris-HCL $(\mathrm{pH}=8.6)$. ALP activity in the cell lysate was assayed using an ALP testing kit (Nanjing Jiancheng Bioengineering Institute, Nanjing, China) following the instruction. The enzyme activity was expressed as micromoles of p-nitrophenol produced per min per mg of protein. The protein content was determined using the BCA Protein Assay kit (Beyotime, Shanghai, China) using BSA as the standard.

2.8. ALP Staining. Cells were washed twice with PBS and fixed with $4 \%$ paraformaldehyde at the room temperature for $10 \mathrm{~min}$, followed by three additional $\mathrm{ddH}_{2} \mathrm{O}$ washes. Then, fixed cells were added with BCIP/NBT solution (Beyotime, Shanghai, China), following the instructions. Stained cell photos were taken using a digital camera.

2.9. Western Blotting Analysis. Proteins were extracted with an MPER protein extraction reagent (Pierce, Rockford, IL, USA) supplemented with the protease inhibitor mixture (Calbiochem, San Diego, CA, USA). The protein samples were subjected to SDS-PAGE using anti-phosphoSmad1/5/ 8 antibody and anti-GAPDH antibody (all from Cell Signaling, Danvers, MA, USA). The relative integrated density of each protein band was determined using an Odyssey Infrared Imaging System (LI-COR Bioscience, Lincoln, NE, USA).

2.10. Statistical Analysis. All experiments were repeated independently at least three times. Data are represented as mean \pm SD. Student's $t$-test was used to determine the significance of differences between two groups, whereas analysis of variance (ANOVA) was used for multiple comparisons. Values of $p<0.05$ were considered significant.

\section{Results}

3.1. Identification of Primary Calvarial Osteoblasts. Initially, we investigated osteogenic characteristics of the primary cells isolated from neonatal rat calvaria. During the differentiating stage, osteoblasts can express and secrete many specific molecules, such as alkaline phosphatase (ALP), osteocalcin (OCN), and Runt-related transcription factor 2 (Runx2). ALP is considered the most abundant glycoprotein in the extracellular matrix, and it is expressed by osteoblasts at the early stage of differentiation [29]. OCN is secreted solely by osteoblasts at the late stage of differentiation [30], and Runx2 is the most important transcription factor regulating osteogenic differentiation and osteoblast activation [31]. In the present study, the results from RT-PCR analysis showed that the primary cells specifically expressed the gene of these osteogenic markers ALP, OCN, and Runx2. Furthermore, the gene expression levels of these three markers were remarkably elevated when the cells were stimulated by $300 \mathrm{ng} / \mathrm{ml}$ BMP-2 (Figure 1(a)). The consistent results were confirmed by quantitative analysis with real-time PCR (Figures 1(b), 1(c), and 1(d)). These results indicated that the primary cells possessed osteogenic properties. Thus, we used these primary osteoblastic cells in the following experiments.

3.2. mRNA Expression Levels of IL-17, IL-22, and IL-23 Receptors in Different Osteoblast Models. It has been proved that IL-17A acts through a heterotrimeric receptor composed of two IL-17RA subunits and one IL-17RC subunit $[32,33]$. Both the IL-22 receptor and IL-23 receptor are heterodimers. The IL-22 receptor consists of two subunits, IL-10R2 and IL$22 \mathrm{R} 1[34,35]$. The IL-23 receptor is composed of IL-12R $\beta 1$ subunit and IL-23R subunit [36]. In rat primary osteoblasts, the RT-PCR analysis showed significant mRNA expression levels of IL-17RA, IL-17RC, and IL-10R2 subunits; marginal levels of IL-22R1 and IL-12R $\beta 1$; and undetectable level of IL23R (Figure 2(a)). Consistently, the results from quantitative real-time PCR confirmed that the mRNA copies of IL-17RA, IL-17RC, and IL-10R2 were above $1 \times 10^{-3}$ standardized with the mRNA copies of GAPDH, while the mRNA copies of the other three subunits were all below $1 \times 10^{-3}$ standardized with the mRNA copies of GAPDH (Figure 2(e)). Besides, there were no obvious changes in the expression levels of these receptor subunits in the presence or absence of BMP2 stimulation. The above results demonstrated the presence of the IL-17 receptor and the absence of IL-22 and IL-23 receptors in rat primary osteoblasts.

In $\mathrm{C} 2 \mathrm{C} 12$ cells, the mRNA of all the 6 interested subunits were mildly detected by semiquantitative RT-PCR, and quantitative real-time RT-PCR showed that the mRNA copies of all the 6 subunits were at the very low levels which were below $6 \times 10^{-4}$ adjusted with the mRNA copies of GAPDH (Figures 2(b) and 2(f)). The similar results were observed in 


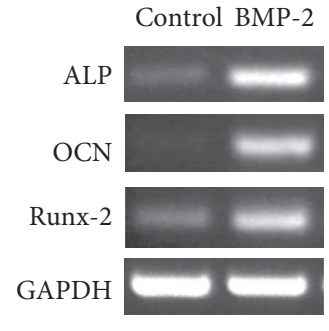

(a)

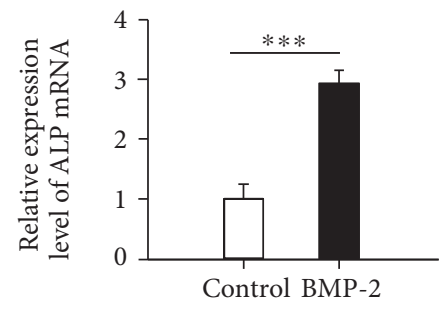

(c)

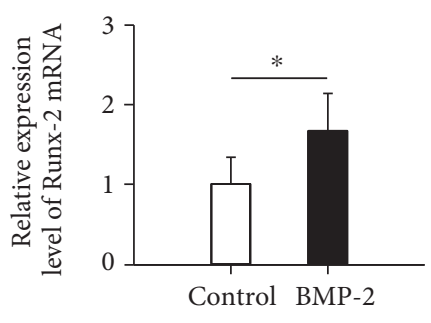

(b)

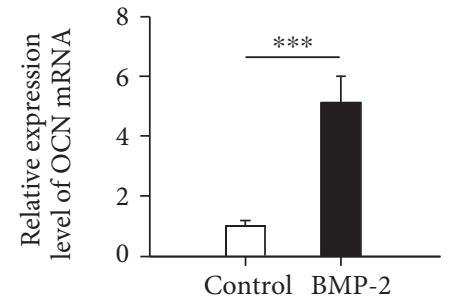

(d)

FIGURE 1: Identification of primary calvarial osteoblasts. The primary osteoblasts were isolated from calvaria of neonatal Sprague-Dawly rats. (a) The gene expression levels of alkaline phosphatase (ALP), osteocalcin (OCN), and Runx-2 were detected by RT-PCR after the cells were cultured in the absence or presence of recombinant human bone morphogenetic protein-2 (BMP-2) (300 ng/ml); GAPDH was used as a gel loading control. (b, c, d) The gene expression levels of ALP, OCN, and Runx-2 were analyzed by quantitative real-time RT-PCR. Compared with the cells without BMP-2 stimulation: ${ }^{*} p<0.05,{ }^{* * *} p<0.001$.

MC3T3-E1 cells in which the mRNA copies of IL-17RA, IL17RC, IL-10R2, IL-22R1, IL-12R $\beta 1$, and IL-23R were all below $1.5 \times 10^{-3}$ adjusted with the mRNA copies of GAPDH (Figures 2(c) and 2(g)). In Saos-2 cells, only mRNA copies of IL-10R2 were above $1 \times 10^{-2}$ standardized with the mRNA copies of GAPDH; the expressions of the other subunits were hardly detected (Figures 2(d) and 2(h)). Stimulation with BMP-2 failed to upregulate the expression levels of IL-17RA, IL-17RC, IL-10R2, IL-22R1, IL-12R $\beta 1$, and IL$23 \mathrm{R}$ in $\mathrm{C} 2 \mathrm{C} 12$ cells, MC3T3-E1 cells, or Saos- 2 cells (Figure 2). These results demonstrated the absence of IL17, IL-22, and IL-23 receptors in C2C12 cells, MC3T3-E1 cells, and Saos- 2 cells.

3.3. Effects of $I L-17, I L-22$, and $I L-23$ on the Proliferation of Rat Primary Calvarial Osteoblasts. The effects of IL-17, IL-22, and IL-23 on proliferation of rat primary calvarial osteoblasts were determined from cell growth kinetics with a CCK-8 assay measuring the metabolic activity of viable cells. As a result, all of IL-17 $(5-125 \mathrm{ng} / \mathrm{ml})$, IL-22 $(5-125 \mathrm{ng} / \mathrm{ml})$, or IL-23 $(5-125 \mathrm{ng} / \mathrm{ml})$ failed to induce the proliferation of osteoblasts (Figures 3(a), 3(b), and 3(c)). Besides, a cell cycle analysis was also conducted in primary osteoblasts treated with IL-17 $(25 \mathrm{mg} / \mathrm{ml})$, IL-22 $(25 \mathrm{mg} / \mathrm{ml})$, and IL-23 $(25 \mathrm{mg} / \mathrm{ml})$ for $24 \mathrm{~h}$. Flow cytometric analysis showed that IL-17, IL-22, and IL-23 did not modulate the proportion of $S$ phase cells compared with the control groups (Figure 3(d)).

3.4. Effects of $I L-17, I L-22$, and $I L-23$ on $m R N A$ Expression of the Markers Associated with Osteogenic Differentiation in Primary Calvarial Osteoblasts. The effects of IL-17, IL-22, and IL-23 on osteogenic differentiation were analyzed in primary calvarial osteoblasts. First, the mRNA expression levels of ALP, OCN, and Runx2 were analyzed in BMP-2-treated primary osteoblasts in the presence or absence of IL-17 (25 mg/ml), IL-22 (25 mg/ml), or IL-23 (25 mg/ml). Stimulation with BMP-2 significantly enhanced the mRNA expression levels of ALP, OCN, and Runx-2 in rat primary osteoblasts (Figures 4(a), 4(b), and 4(c)). IL-17 slightly inhibited the BMP-2-induced expression levels of ALP, OCN, and Runx-2 mRNA, while IL-22 and IL-23 failed to influence the BMP-2-induced mRNA expression levels of these differentiation markers (Figures 4(a), 4(b), and 4(c)). These results were further confirmed by quantitative realtime RT-PCR (Figures 4(d), 4(e), and 4(f)). These data demonstrated that IL-17 could inhibit osteogenic differentiation of rat osteoblasts, but IL-22 and IL-23 had a null effect on the differentiation.

3.5. Effects of $I L-17, I L-22$, and IL-23 on the ALP Activity of Primary Osteoblasts. To further validate the effects of IL-17, IL-22, and IL-23 on the osteoblastic differentiation in primary calvarial osteoblasts, ALP staining and an ALP activity assay were carried out. The primary osteoblasts were induced to be differentiated by BMP-2 $(300 \mathrm{ng} / \mathrm{ml})$ and were further treated with or without IL-17 $(25 \mathrm{ng} / \mathrm{ml}), \mathrm{IL}-22(25 \mathrm{ng} / \mathrm{ml})$, and IL-23 $(25 \mathrm{ng} / \mathrm{ml})$ for 7 days. With the induction by BMP-2, the ALP activity in primary osteoblasts was remarkably elevated, which was reduced by IL-17, but not by IL-22 or IL-23 (Figure 5(a)). The inhibitory effect of IL-17 (5-125 ng/ml) on ALP activity was dose-dependent (Figure 5(c)). In the ALP staining test, it was confirmed that the BMP-2-induced ALP activity was inhibited by IL- 


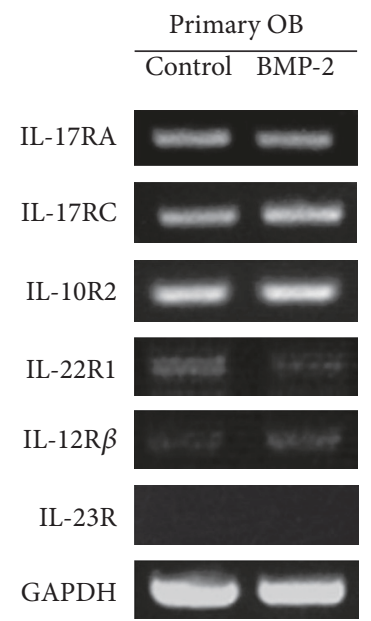

(a)

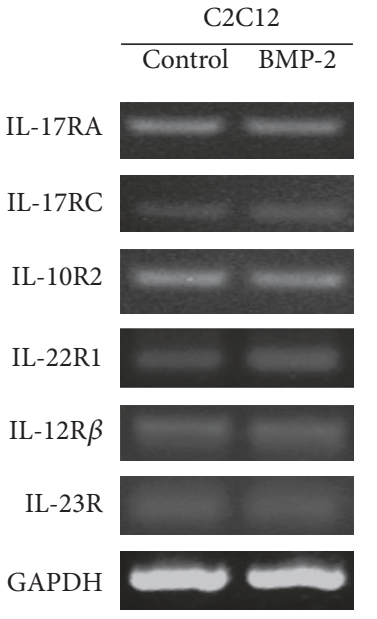

(b)

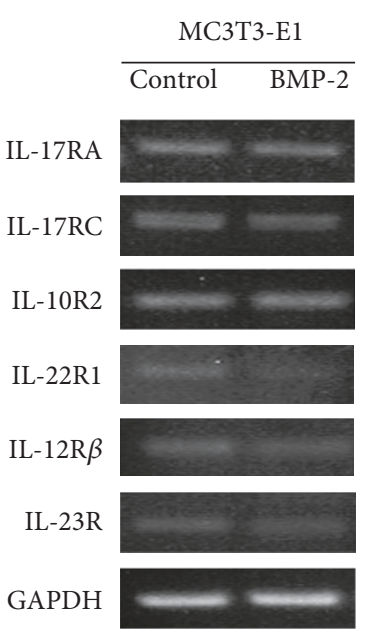

(c)

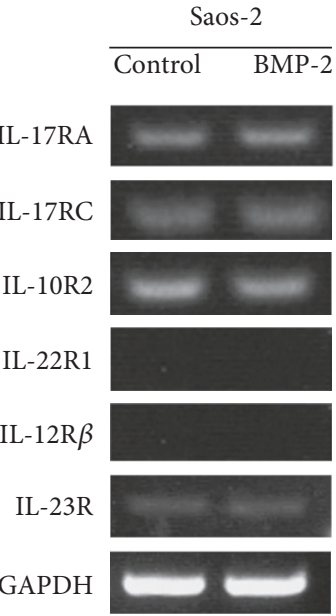

(d)
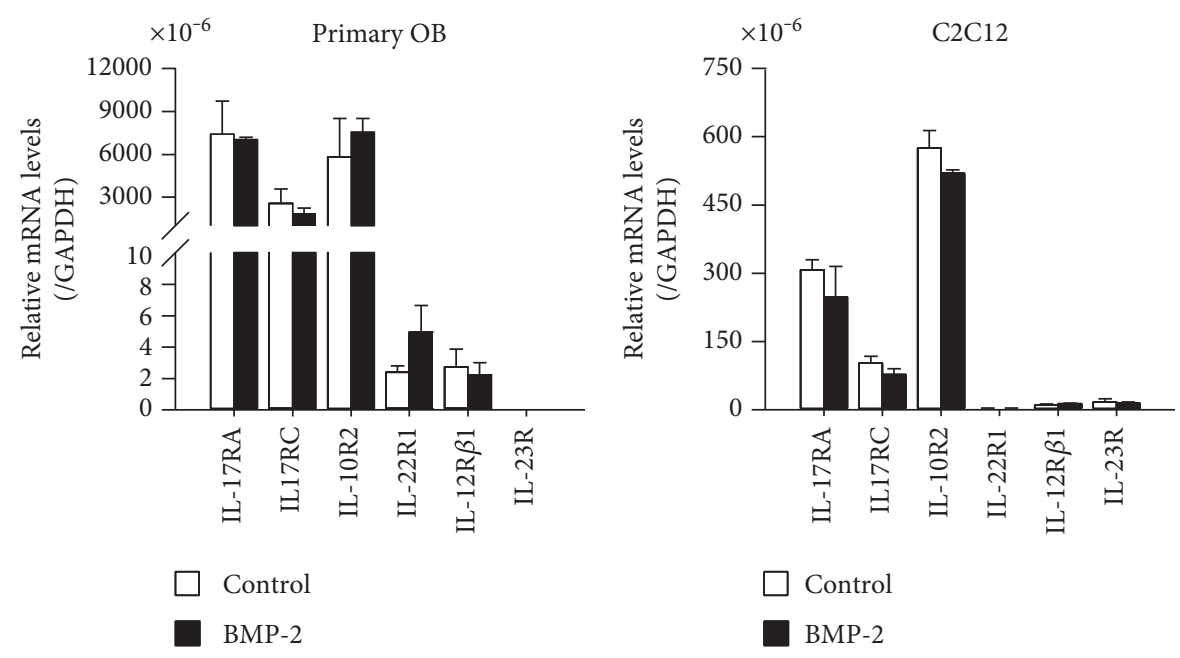

$\square$ Control

- BMP-2

(e)

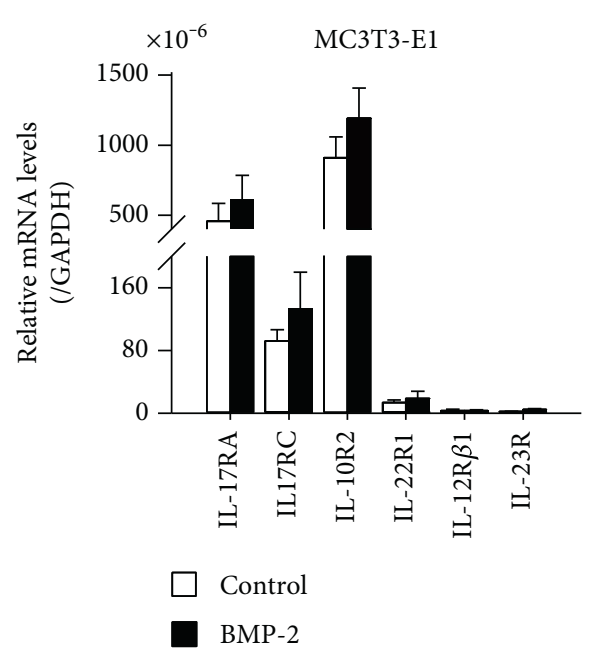

(g)

(f)

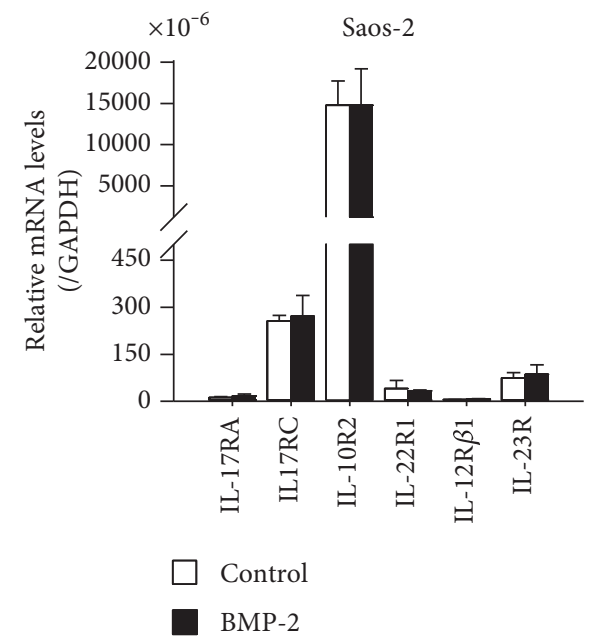

(h)

FIGURE 2: Gene expression levels of IL-17, IL-22, and IL-23 receptors in different osteoblast (OB) models. (a-d) The gene expression levels of IL-17, IL-22, and IL-23 receptors in primary osteoblasts, C2C12, MC3T3-E1, and Saos-2 were determined by RT-PCR analysis after the cells were cultured in the absence or presence of BMP-2 $(300 \mathrm{ng} / \mathrm{ml})$; GAPDH was used as a gel loading control. (e-h) The gene expression levels of IL-17, IL-22, and IL-23 receptors in primary osteoblasts, C2C12, MC3T3-E1, and Saos-2 were analyzed by quantitative real-time RT-PCR; the copies of the receptor mRNA was standardized with the copies of GAPDH mRNA. 


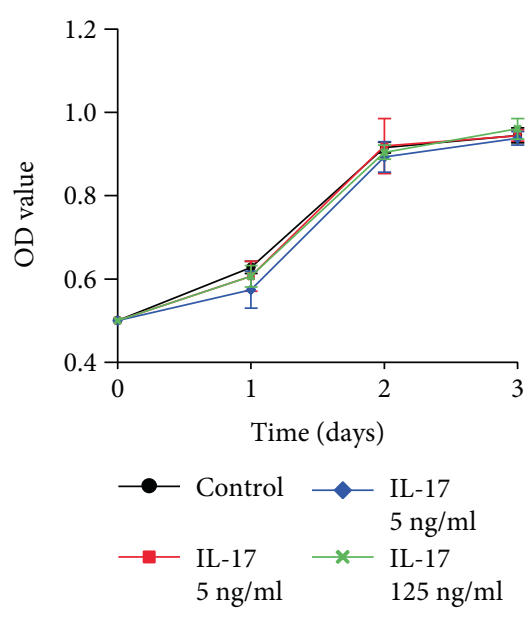

(a)

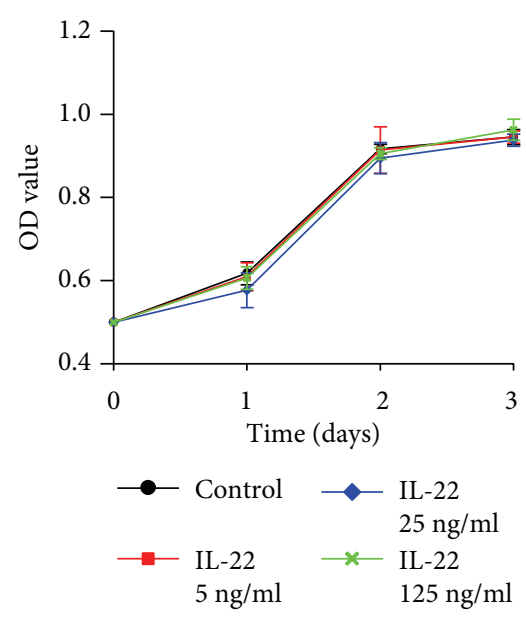

(b)

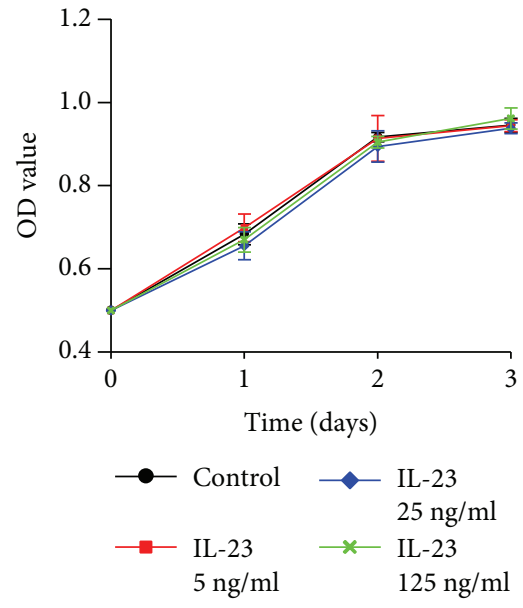

(c)

Control

IL-17 (25 ng/ml)
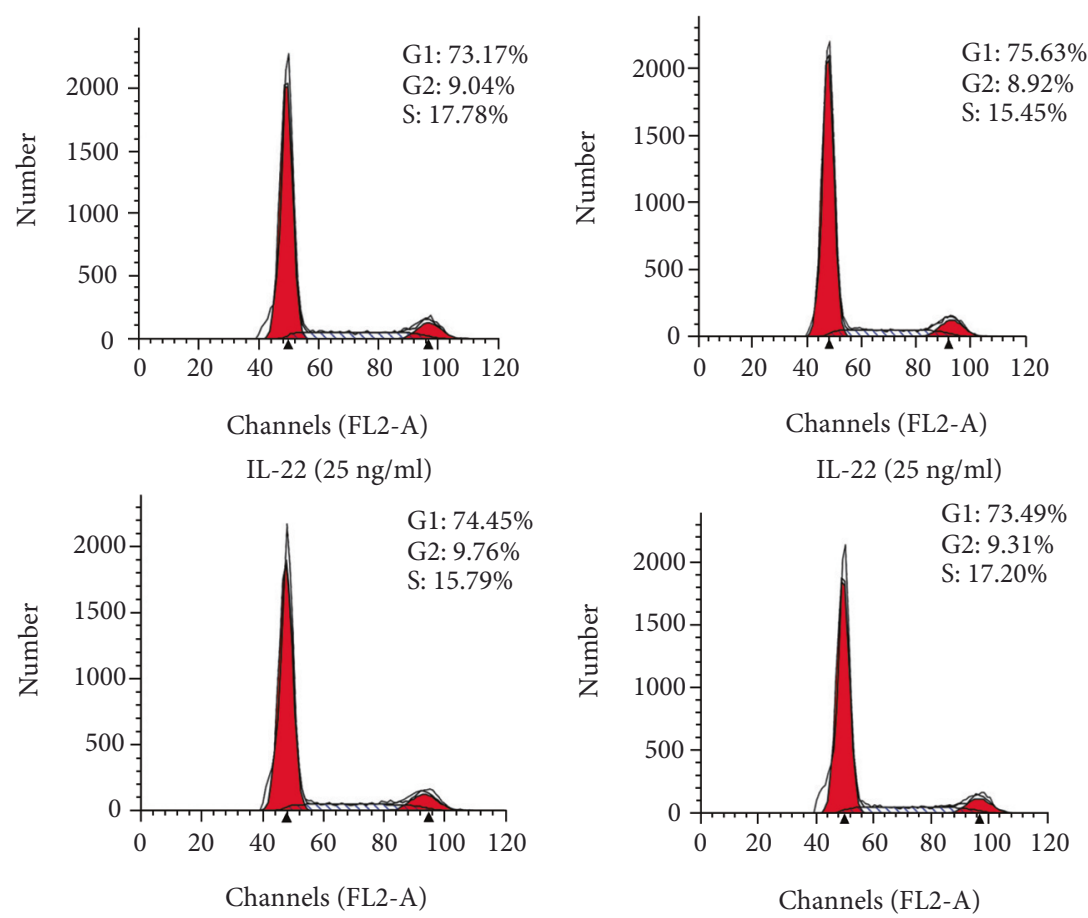

(d)

Figure 3: The effects of IL-17, IL-22, and IL-23 on the proliferation and cell cycle of the rat primary osteoblasts. (a-c) Proliferation of primary osteoblasts was tested by a CCK- 8 assay after the cells were treated with various concentrations of IL-17, IL-22, and IL-23 (0, 5, 25 , and 125 ng/ $\mathrm{ml}$ ) for different periods $(24 \mathrm{~h}, 48 \mathrm{~h}$, and $72 \mathrm{~h}$ ). (d) Cell cycle analysis of primary osteoblasts were determined by flow cytometry after the cells were stimulated with or without IL-17 (25 ng/ml), IL-22 (25 ng/ml), and IL-23 (25 ng/ml) for $24 \mathrm{~h}$.

17 in a dose-dependent manner but not affected by IL-22 or IL-23 (Figures 5(b) and 5(d)).

\subsection{IL-17 Inhibits BMP-2-Induced Osteoblastic Differentiation} via the BMP/Smad-Independent Pathway. BMP-2 is a potent osteoblastic differentiation inducer which signals though Smads. To determine whether IL-17 exerts an inhibitory effect on BMP-2-induced osteoblastic differentiation through crosstalk with the canonical BMP/Smad signaling, rat primary osteoblasts were treated with BMP-2 in the presence or absence of IL-17. The changes in phosphorylated
Smad1/5/8 were analyzed by Western blotting. When the cells were stimulated with BMP-2 alone, Smad1/5/8 phosphorylation significantly increased. Treatment with IL-17 did not affect the BMP-2-induced phosphorylation of Smad1/5/8 (Figure 6).

\section{Discussion}

For the first time, it was shown that rat primary osteoblasts constitutively expressed both subunits of IL-17 receptors, but BMP-2, a potent inducer of osteoblast differentiation, 


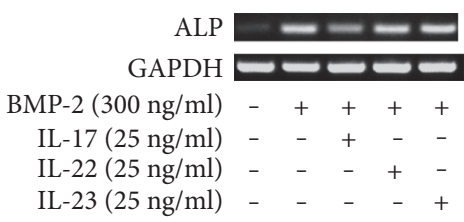

(a)

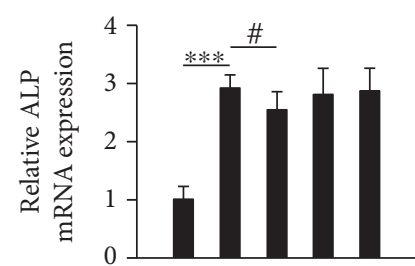

BMP-2 (300 ng/ml)

IL-17 $(25 \mathrm{ng} / \mathrm{ml})$

IL-22 $(25 \mathrm{ng} / \mathrm{ml})$

IL-23 (25 ng/ml)

(d)

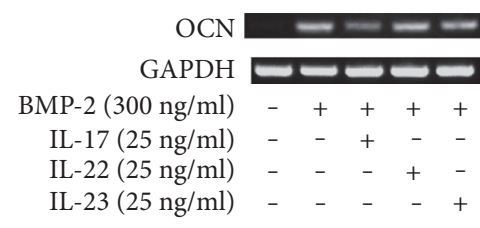

(b)

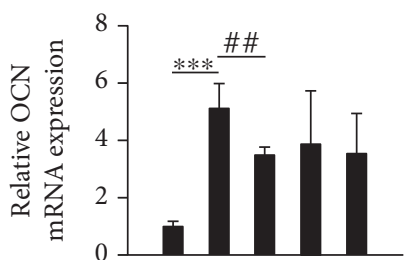

BMP-2 (300 ng/ml) - + + + +

IL-17 $(25 \mathrm{ng} / \mathrm{ml})-{ }_{-}+-$

IL-22 $(25 \mathrm{ng} / \mathrm{ml})$

IL-23 $(25 \mathrm{ng} / \mathrm{ml})$

(e)

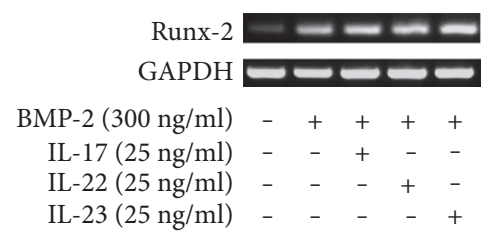

(c)

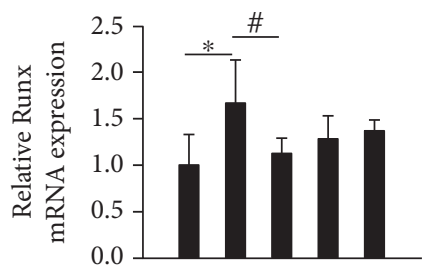

BMP-2 $(300 \mathrm{ng} / \mathrm{ml})-+++$

IL-17 $(25 \mathrm{ng} / \mathrm{ml})-{ }_{-}+-$

IL-22 $(25 \mathrm{ng} / \mathrm{ml}) \quad-\quad-\quad+-$

$\mathrm{IL}-23(25 \mathrm{ng} / \mathrm{ml}) \quad-\quad-\quad+$

(f)

FIgURE 4: The effects of IL-17, IL-22, and IL-23 on mRNA expression of markers associated with osteogenic differentiation in primary calvarial osteoblasts. $(\mathrm{a}, \mathrm{b}, \mathrm{c})$ Phenotypic markers of osteogenic differentiation (ALP, OCN, and Runx-2) were determined by RT-PCR in cells cultured with the differentiation inducer BMP-2 $(300 \mathrm{ng} / \mathrm{ml})$ in the presence or absence of IL-17 (25 mg/ml), IL-22 (25 mg/ml), or IL$23(25 \mathrm{mg} / \mathrm{ml})$ for $24 \mathrm{~h}$. GAPDH was used as an internal control. (d, e, f) Phenotypic markers of osteogenic differentiation (ALP, OCN, and Runx-2) were analyzed by quantitative real-time RT-PCR. The copy number of ALP, OCN, and Runx-2 mRNA was standardized with the copy number of GAPDH mRNA. ${ }^{*} p<0.05,{ }^{* * *} p<0.001$ compared with untreated control; ${ }^{*} p<0.05,{ }^{\# \#} p<0.01$ compared with the cells stimulated with BMP-2 alone.

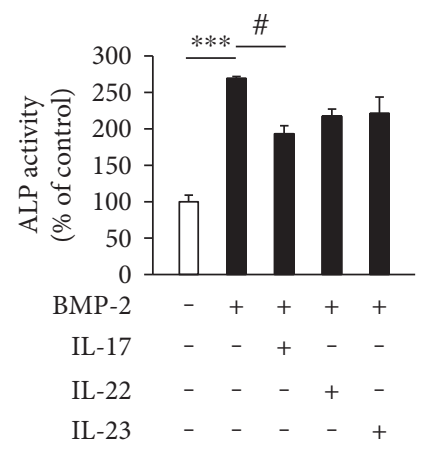

(a)

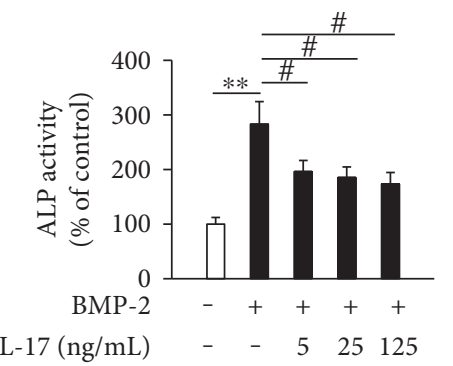

(c)

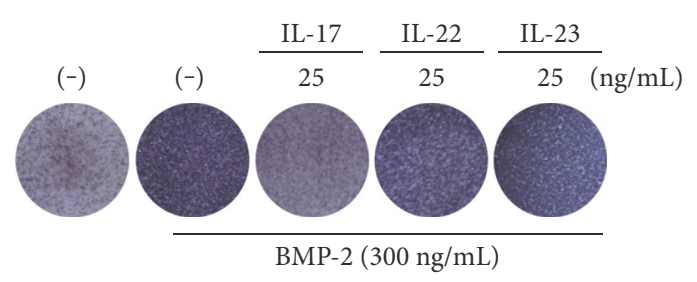

(b)

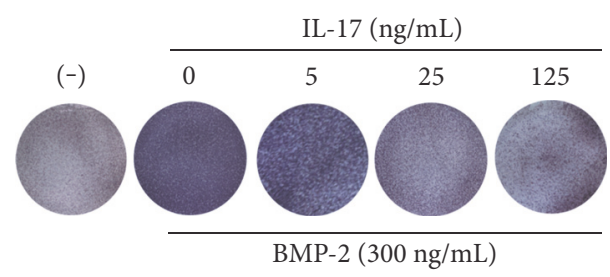

(d)

FIGURE 5: The effects of IL-17 on ALP activity and ALP mass of primary osteoblasts. (a) ALP activity in primary osteoblasts cultured with BMP-2 $(300 \mathrm{ng} / \mathrm{ml})$ in the presence of IL-17 $(25 \mathrm{ng} / \mathrm{ml})$, IL-22 $(25 \mathrm{ng} / \mathrm{ml})$, or IL-23 $(25 \mathrm{ng} / \mathrm{ml})$ for 7 days. ${ }^{* * *} p<0.001$ compared with untreated control; ${ }^{\#} p<0.05$ compared with the cells stimulated with BMP-2 alone. (b) Staining for ALP in primary osteoblasts cultured with BMP-2 $(300 \mathrm{ng} / \mathrm{ml})$ in the presence of IL-17 $(25 \mathrm{ng} / \mathrm{ml})$, IL-22 $(25 \mathrm{ng} / \mathrm{ml})$, or IL-23 $(25 \mathrm{ng} / \mathrm{ml})$ for 7 days. (c) ALP activity in primary osteoblasts cultured with BMP-2 $(300 \mathrm{ng} / \mathrm{ml})$ in the presence of different concentrations of IL-17 $(0,5,25$, and $125 \mathrm{ng} / \mathrm{ml})$ for 7 days. ${ }^{* *} p<0.01$ compared with untreated control; ${ }^{*} p<0.05$ compared with the cells stimulated with BMP-2 alone. (d) Staining for ALP in primary osteoblasts cultured with BMP-2 $(300 \mathrm{ng} / \mathrm{ml})$ in the presence of different concentrations of IL-17 (0, 5, 25, and $125 \mathrm{ng} / \mathrm{ml}$ ) for 7 days. 


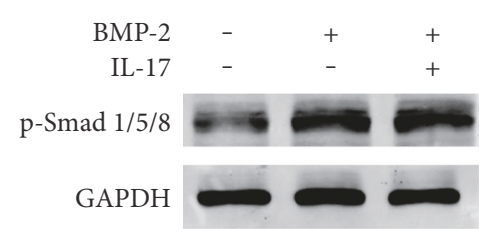

FIGURE 6: Effect of IL-17 on BMP-2-induced phosphorylation of Smad1/5/8. The rat primary osteoblasts were treated with BMP-2 $(300 \mathrm{ng} / \mathrm{ml})$ in the presence or absence of IL-17 $(25 \mathrm{ng} / \mathrm{ml})$ for $48 \mathrm{~h}$. The intracellular level of phosphorylated Smad1/5/8 (p-Smad1/5/8) was analyzed by Western blotting.

did not modulate the expression level of IL-17 receptors. Moreover, IL-17 significantly inhibited the differentiation of osteoblasts induced by BMP-2. The rat osteoblasts did not express the intact receptors for IL-22 or IL-23, and neither IL-22 nor IL-23 modulated the differentiation of the osteoblasts. The most commonly used osteoblast-like cell lines, C2C12 cells, MC3T3-E1 cells, and Saos- 2 cells, were lack of the expression of IL-17, IL-22, and IL-23 receptors.

Chronic inflammation and pathologic osteogenesis are two major characteristics of AS. Previous studies have revealed that a series of immune disorders exist in AS patients $[8,37]$. However, the mechanisms of pathologic osteogenesis and the relationship between inflammation and pathologic osteogenesis have not yet been fully elucidated. Some researchers have suggested that the development of chronic inflammation and osteogenesis may not be synchronized in AS, indicating that pathologic osteogenesis is a relatively independent process with little relation to chronic inflammation [38-40]. Conversely, results of other studies consider chronic inflammation, which predominates in AS, to be the main cause of pathologic osteogenesis [41, 42]. Furthermore, several previous studies have shown that the IL-23/IL-17 axis exerts potent effects on bone remodeling which indicates the relationship between inflammatory factors and bone formation. In a murine model with overexpression of IL-23, Sherlock et al. [13] demonstrated the pivotal role for the cytokines IL-23 and IL-22 in the development of enthesitis and bone formation, respectively. So we tried to study the direct effects of IL-17, IL-22, and IL-23.

At the first step, we analyzed the expression levels of IL-17, IL-22, and IL-23 receptors in rat primary osteoblasts and the most commonly used osteoblast-like cell lines.

The murine multidifferentiating potential cell line $\mathrm{C} 2 \mathrm{C} 12$, the cell line Saos-2 derived from human osteosarcoma, and the murine preosteoblast cell line MC3T3-E1 all have been demonstrated to have significant osteogenic characteristics [43-45]. It is well known that the primary osteoblast is an optimal choice for bone researches in vitro, but it has some disadvantages in the limitation and inconvenience of acquisition of cells. On the other hand, various osteoblast-like cell lines derived from different sources are with multiple advantages, such as the ready availability of large numbers of cells, the homogeneity of the cell cultures, and the expected invariability of the phenotype. Unfortunately, none of the selected osteoblast cell lines express the both subunits of the receptors for IL-17, IL-22, or IL-23. Previous studies have proved that the gene expression and the levels of osteogenic phenotypes vary greatly when the primary osteoblasts and osteoblastlike cells are at the different differentiation stages [29, 40, 41]. Thus, we further detected the gene expression levels of the above receptors in these cell lines during differentiation induced by BMP-2. However, BMP-2 failed to upregulate the expression levels of the above receptors in these cells. In the osteoblast cell line CRL-12424, IL-22 was shown to upregulate mRNA expression of factors that promote bone formation, including Wnt10b, BMP4, and ALP [13]. However, we failed to purchase CRL-12424 cells, and the reason for inconsistent results of IL-22 in the osteoblast cell lines remains unknown. So we have to use the rat primary osteoblasts in the following experiments.

According to the results from semiquantitative and quantitative RT-PCR analysis, IL-17 receptors (IL-17RA and IL-17RC) were clearly shown while IL-22 receptors and IL-23 receptors were absent in the rat primary osteoblasts. These results are consistent with those of previous studies which demonstrated the presence of IL-17 receptors in rat primary osteoblasts [46] and the absence of IL-23 receptors in mouse primary osteoblasts [47]. Moreover, no matter whether the cells were stimulated with BMP-2 or not, the mRNA expression levels of IL-17, IL-22, and IL-23 receptors remained the same.

At the next step, we studied the direct effects of IL-17, IL-22, and IL-23 on osteoblasts in vitro. Consistent with the deficit of IL-22 and IL-23 receptors in rat primary osteoblasts, both IL-22 and IL-23 failed to show any effects on the proliferation and differentiation. Although IL-17 did not modulate the proliferation of rat osteoblasts, IL-17 inhibited the BMP-2-induced differentiation of rat primary osteoblasts in a dose-dependent manner, which further supported the expression of the IL-17 receptor by rat osteoblasts. These results are consistent with the report by Kim et al. [46], in which IL-17 inhibited osteoblast differentiation and bone regeneration in rats. On the contrary, Huang et al. [48] found that IL-17 stimulated the proliferation of human mesenchymal stem cells (MSCs) and induced MSCs to differentiate into osteoblasts.

This kind of paradoxical effects on bone homeostasis is also found in TNF- $\alpha$. TNF- $\alpha$ which has been proved to involve in the pathogenesis of AS classically is supposed to play a pivotal role in the regulation of bone homeostasis by stimulating osteoclastogenesis and inhibiting osteoblast function [49-51]. However, opposite findings suggest that TNF- $\alpha$ may also induce osteogenic differentiation [52-54]. This paradoxical effect of TNF- $\alpha$ in inhibiting or facilitating osteoblastogenesis lies in the differentiation stage of the responding cells [55]. Similarly, the inconsistent effects of IL-17 on osteogenesis may also be influenced by the differentiation state of the cell type, as MSCs are pluripotent progenitor cells that can differentiate into a variety of cell types.

Overall, IL-17, IL-22, and IL-23 did not show direct promoting effect on rat primary osteoblasts in vitro, but these data did not rule out any indirect effects of these inflammatory factors to facilitate osteoblast differentiation in vivo, which are awaiting further studies to clarify. The interplay 
between inflammatory factors and new bone formation in AS is still challenging.

BMP-2 modulates osteoblast differentiation through the canonical BMP/Smad pathway and noncanonical BMP pathways [56-58]. In the canonical BMP/Smad pathway, the activated BMP receptors subsequently propagate the BMP signals by phosphorylating BMP-specific Smad1/5/8. Then, the phosphorylated Smad1/5/8 binds to Smad4, and the complex is transported to the nucleus to activate the osteogenicspecific transcription factor Runx2. Runx2 has an essential role in osteoblast differentiation of stem cells and directly stimulates transcription of its important downstream target genes, including OCN, ALP, type I collagen (COL1A1), and osteopontin (OPN). In the present study, IL-17 failed to inhibit the phosphorylation of $\mathrm{Smad} 1 / 5 / 8$, which was induced by BMP-2. This finding suggests that the inhibitory effect of IL-17 on BMP-2-induced osteoblast differentiation is independent of the BMP/Smad signaling pathway, which is also supported by other studies. For example, TNF- $\alpha$ suppressed the expression of Runx 2 and the transcription of osteogenic genes by interfering with the DNA binding of Smad proteins instead of inhibiting phosphorylation of Smad1/5/8 or nuclear translocation of the Smad1/Smad4 complex [59]. Huang et al. [60] found that TNF- $\alpha /$ IL- $1 \beta$ regulated BMP-2-induced osteoblastic differentiation by activating MAPK signaling pathways instead of the BMP-2/Smad signaling pathway. Therefore, these data suggest the existence of alternative pathways besides BMP/Smad signaling to regulate BMP-2-induced osteoblast differentiation.

In conclusion, rat primary osteoblasts constitutively express IL-17 receptors but lack IL-22 and IL-23 receptors. None of C2C12 cells, MC3T3-E1 cells, and Saos-2 cells express receptors for IL-17, IL-22, and IL-23. IL-17 inhibits BMP-2-induced osteoblast differentiation via the $\mathrm{BMP} /$ Smad-independent pathway.

\section{Conflicts of Interest}

The authors declare that they have no competing interests.

\section{Authors' Contributions}

Jing-Ru Zhang, Dan-Dan Pang, and Sheng-Ming Dai conceived and conducted the study, analyzed and interpreted the data, and participated in drafting the manuscript. Qiang Tong, Ding-Feng Su, and Xia Liu made substantial contributions to the data analysis, data interpretation, and drafting of the manuscript. All authors read and approved the final manuscript. Jing-Ru Zhang and Dan-Dan Pang contributed equally to this work.

\section{Acknowledgments}

Sheng-Ming Dai was supported by a grant from the National Key Basic Research Program of China (2014CB541804) and a grant from the National Natural Science Foundation of China (no. 81471604).

\section{References}

[1] J. Braun and J. Sieper, "Ankylosing spondylitis," Lancet, vol. 369, no. 9570, pp. 1379-1390, 2007.

[2] J. Braun and X. Baraliakos, "Imaging of axial spondyloarthritis including ankylosing spondylitis," Annals of the Rheumatic Diseases, vol. 70, Supplement 1, pp. i97-103, 2011.

[3] Wellcome Trust Case Control Consortium, Australo-AngloAmerican Spondylitis Consortium (TASC), P. R. Burton et al., "Association scan of 14,500 nonsynonymous SNPs in four diseases identifies autoimmunity variants," Nature Genetics, vol. 39, no. 11, pp. 1329-1337, 2007.

[4] Australo-Anglo-American Spondyloarthritis Consortium (TASC), J. D. Reveille, A. M. Sims et al., "Genome-wide association study of ankylosing spondylitis identifies non-MHC susceptibility loci," Nature Genetics, vol. 42, no. 2, pp. 123127, 2010.

[5] S. I. Davidson, L. Jiang, A. Cortes et al., "Brief report: high-throughput sequencing of IL23R reveals a low-frequency, nonsynonymous single-nucleotide polymorphism that is associated with ankylosing spondylitis in a Han Chinese population," Arthritis and Rheumatism, vol. 65, no. 7, pp. 1747-1752, 2013.

[6] R. Singh, A. Aggarwal, and R. Misra, "Th1/Th17 cytokine profiles in patients with reactive arthritis/undifferentiated spondyloarthropathy," The Journal of Rheumatology, vol. 34, no. 11, pp. 2285-2290, 2007.

[7] D. Wendling, J. P. Cedoz, E. Racadot, and G. Dumoulin, "Serum IL-17, BMP-7, and bone turnover markers in patients with ankylosing spondylitis," Joint, Bone, Spine, vol. 74, no. 3, pp. 304-305, 2007.

[8] C. Jandus, G. Bioley, J. P. Rivals, J. Dudler, D. Speiser, and P. Romero, "Increased numbers of circulating polyfunctional Th17 memory cells in patients with seronegative spondylarthritides," Arthritis and Rheumatism, vol. 58, no. 8, pp. 2307-2317, 2008.

[9] H. Shen, J. C. Goodall, and J. S. Hill Gaston, "Frequency and phenotype of peripheral blood Th17 cells in ankylosing spondylitis and rheumatoid arthritis," Arthritis and Rheumatism, vol. 60, no. 6, pp. 1647-1656, 2009.

[10] P. Jacques, K. Venken, K. Van Beneden et al., "Invariant natural killer $\mathrm{T}$ cells are natural regulators of murine spondylarthritis," Arthritis and Rheumatism, vol. 62, no. 4, pp. 988-999, 2010.

[11] P. Bowness, A. Ridley, J. Shaw et al., “Th17 cells expressing KIR3DL2+ and responsive to HLA-B27 homodimers are increased in ankylosing spondylitis," Journal of Immunology, vol. 186, no. 4, pp. 2672-2680, 2011.

[12] T. J. Kenna, S. I. Davidson, R. Duan et al., "Enrichment of circulating interleukin-17-secreting interleukin-23 receptorpositive gamma/delta T cells in patients with active ankylosing spondylitis," Arthritis and Rheumatism, vol. 64, no. 5, pp. 1420-1429, 2012.

[13] J. P. Sherlock, B. Joyce-Shaikh, S. P. Turner et al., "IL-23 induces spondyloarthropathy by acting on ROR-gammat+ CD3+CD4-CD8- entheseal resident T cells," Nature Medicine, vol. 18, no. 7, pp. 1069-1076, 2012.

[14] X. Wang, Z. Lin, Q. Wei, Y. Jiang, and J. Gu, "Expression of IL-23 and IL-17 and effect of IL-23 on IL-17 production in ankylosing spondylitis," Rheumatology International, vol. 29, no. 11, pp. 1343-1347, 2009. 
[15] M. L. DeLay, M. J. Turner, E. I. Klenk, J. A. Smith, D. P. Sowders, and R. A. Colbert, "HLA-B27 misfolding and the unfolded protein response augment interleukin-23 production and are associated with Th17 activation in transgenic rats," Arthritis and Rheumatism, vol. 60, no. 9, pp. 26332643, 2009.

[16] M. Ruutu, G. Thomas, R. Steck et al., "Beta-glucan triggers spondylarthritis and Crohn's disease-like ileitis in SKG mice," Arthritis and Rheumatism, vol. 64, no. 7, pp. 2211-2222, 2012.

[17] S. Glatigny, I. Fert, M. A. Blaton et al., "Proinflammatory Th17 cells are expanded and induced by dendritic cells in spondylarthritis-prone HLA-B27-transgenic rats," Arthritis and Rheumatism, vol. 64, no. 1, pp. 110-120, 2012.

[18] D. Baeten, X. Baraliakos, J. Braun et al., "Anti-interleukin-17A monoclonal antibody secukinumab in treatment of ankylosing spondylitis: a randomised, double-blind, placebo-controlled trial," Lancet, vol. 382, no. 9906, pp. 1705-1713, 2013.

[19] I. E. Adamopoulos, C. C. Chao, R. Geissler et al., "Interleukin$17 \mathrm{~A}$ upregulates receptor activator of NF-kappaB on osteoclast precursors," Arthritis Research \& Therapy, vol. 12, no. 1, article R29, 2010.

[20] K. Sato, A. Suematsu, K. Okamoto et al., "Th17 functions as an osteoclastogenic helper $\mathrm{T}$ cell subset that links $\mathrm{T}$ cell activation and bone destruction," The Journal of Experimental Medicine, vol. 203, no. 12, pp. 2673-2682, 2006.

[21] I. E. Adamopoulos and E. P. Bowman, "Immune regulation of bone loss by Th17 cells," Arthritis Research \& Therapy, vol. 10, no. 5, p. 225, 2008.

[22] S. Kotake, N. Udagawa, N. Takahashi et al., "IL-17 in synovial fluids from patients with rheumatoid arthritis is a potent stimulator of osteoclastogenesis," The Journal of Clinical Investigation, vol. 103, no. 9, pp. 1345-1352, 1999.

[23] T. Yago, Y. Nanke, M. Kawamoto et al., "IL-23 induces human osteoclastogenesis via IL-17 in vitro, and anti-IL-23 antibody attenuates collagen-induced arthritis in rats," Arthritis Research \& Therapy, vol. 9, no. 5, article R96, 2007.

[24] L. Chen, X. Q. Wei, B. Evans, W. Jiang, and D. Aeschlimann, "IL-23 promotes osteoclast formation by up-regulation of receptor activator of NF-kappaB (RANK) expression in myeloid precursor cells," European Journal of Immunology, vol. 38, no. 10, pp. 2845-2854, 2008.

[25] C. L. Langrish, Y. Chen, W. M. Blumenschein et al., "IL-23 drives a pathogenic $\mathrm{T}$ cell population that induces autoimmune inflammation," The Journal of Experimental Medicine, vol. 201, no. 2, pp. 233-240, 2005.

[26] A. Bakker and J. Klein-Nulend, "Osteoblast isolation from murine calvariae and long bones," Methods in Molecular Medicine, vol. 80, pp. 19-28, 2003.

[27] M. Ishiyama, H. Tominaga, M. Shiga, K. Sasamoto, Y. Ohkura, and K. Ueno, "A combined assay of cell viability and in vitro cytotoxicity with a highly water-soluble tetrazolium salt, neutral red and crystal violet," Biological \& Pharmaceutical Bulletin, vol. 19, no. 11, pp. 1518-1520, 1996.

[28] E. Smith, R. A. Redman, C. R. Logg, G. A. Coetzee, N. Kasahara, and B. Frenkel, "Glucocorticoids inhibit developmental stage-specific osteoblast cell cycle. Dissociation of cyclin A-cyclin-dependent kinase 2 from E2F4-p130 complexes," The Journal of Biological Chemistry, vol. 275, no. 26, pp. 19992-20001, 2000.

[29] T. A. Owen, M. Aronow, V. Shalhoub et al., "Progressive development of the rat osteoblast phenotype in vitro: reciprocal relationships in expression of genes associated with osteoblast proliferation and differentiation during formation of the bone extracellular matrix," Journal of Cellular Physiology, vol. 143, no. 3, pp. 420-430, 1990.

[30] P. V. Hauschka, J. B. Lian, D. E. Cole, and C. M. Gundberg, "Osteocalcin and matrix Gla protein: vitamin K-dependent proteins in bone," Physiological Reviews, vol. 69, no. 3, pp. 990-1047, 1989.

[31] M. Bruderer, R. G. Richards, M. Alini, and M. J. Stoddart, "Role and regulation of RUNX2 in osteogenesis," European Cells \& Materials, vol. 28, pp. 269-286, 2014.

[32] D. Toy, D. Kugler, M. Wolfson et al., "Cutting edge: interleukin 17 signals through a heteromeric receptor complex," Journal of Immunology, vol. 177, no. 1, pp. 36-39, 2006.

[33] S. L. Gaffen, "Structure and signalling in the IL-17 receptor family," Nature Reviews. Immunology, vol. 9, no. 8, pp. 556$567,2009$.

[34] L. Dumoutier, J. Louahed, and J. C. Renauld, "Cloning and characterization of IL-10-related T cell-derived inducible factor (IL-TIF), a novel cytokine structurally related to IL-10 and inducible by IL-9," Journal of Immunology, vol. 164, no. 4, pp. 1814-1819, 2000.

[35] L. Dumoutier, E. Van Roost, D. Colau, and J. C. Renauld, "Human interleukin-10-related T cell-derived inducible factor: molecular cloning and functional characterization as an hepatocyte-stimulating factor," Proceedings of the National Academy of Sciences of the United States of America, vol. 97, no. 18, pp. 10144-10149, 2000.

[36] B. Oppmann, R. Lesley, B. Blom et al., "Novel p19 protein engages IL-12p40 to form a cytokine, IL-23, with biological activities similar as well as distinct from IL-12," Immunity, vol. 13, no. 5, pp. 715-725, 2000.

[37] L. Limon-Camacho, M. I. Vargas-Rojas, J. Vazquez-Mellado et al., "In vivo peripheral blood proinflammatory $\mathrm{T}$ cells in patients with ankylosing spondylitis," The Journal of Rheumatology, vol. 39, no. 4, pp. 830-835, 2012.

[38] W. P. Maksymowych, D. Elewaut, and G. Schett, "Motion for debate: the development of ankylosis in ankylosing spondylitis is largely dependent on inflammation," Arthritis and Rheumatism, vol. 64, no. 6, pp. 1713-1719, 2012.

[39] D. van der Heijde, R. Landewe, S. Einstein et al., "Radiographic progression of ankylosing spondylitis after up to two years of treatment with etanercept," Arthritis and Rheumatism, vol. 58, no. 5, pp. 1324-1331, 2008.

[40] R. J. Lories, I. Derese, C. de Bari, and F. P. Luyten, "Evidence for uncoupling of inflammation and joint remodeling in a mouse model of spondylarthritis," Arthritis and Rheumatism, vol. 56, no. 2, pp. 489-497, 2007.

[41] W. P. Maksymowych, P. Chiowchanwisawakit, T. Clare, S. J. Pedersen, M. Ostergaard, and R. G. Lambert, "Inflammatory lesions of the spine on magnetic resonance imaging predict the development of new syndesmophytes in ankylosing spondylitis: evidence of a relationship between inflammation and new bone formation," Arthritis and Rheumatism, vol. 60, no. 1, pp. 93-102, 2009.

[42] P. Chiowchanwisawakit, R. G. Lambert, B. Conner-Spady, and W. P. Maksymowych, "Focal fat lesions at vertebral corners on magnetic resonance imaging predict the development of new syndesmophytes in ankylosing spondylitis," Arthritis and Rheumatism, vol. 63, no. 8, pp. 2215-2225, 2011. 
[43] G. Bilbe, E. Roberts, M. Birch, and D. B. Evans, "PCR phenotyping of cytokines, growth factors and their receptors and bone matrix proteins in human osteoblast-like cell lines," Bone, vol. 19, no. 5, pp. 437-445, 1996.

[44] D. Wang, K. Christensen, K. Chawla, G. Xiao, P. H. Krebsbach, and R. T. Franceschi, "Isolation and characterization of MC3T3-E1 preosteoblast subclones with distinct in vitro and in vivo differentiation/mineralization potential," Journal of Bone and Mineral Research, vol. 14, no. 6, pp. 893-903, 1999.

[45] T. Katagiri, A. Yamaguchi, M. Komaki et al., "Bone morphogenetic protein-2 converts the differentiation pathway of $\mathrm{C} 2 \mathrm{C} 12$ myoblasts into the osteoblast lineage," The Journal of Cell Biology, vol. 127, no. 6, Part 1, pp. 1755-1766, 1994.

[46] Y. G. Kim, J. W. Park, J. M. Lee et al., "IL-17 inhibits osteoblast differentiation and bone regeneration in rat," Archives of Oral Biology, vol. 59, no. 9, pp. 897-905, 2014.

[47] S. Kamiya, C. Nakamura, T. Fukawa et al., "Effects of IL-23 and IL-27 on osteoblasts and osteoclasts: inhibitory effects on osteoclast differentiation," Journal of Bone and Mineral Metabolism, vol. 25, no. 5, pp. 277-285, 2007.

[48] H. Huang, H. J. Kim, E. J. Chang et al., "IL-17 stimulates the proliferation and differentiation of human mesenchymal stem cells: implications for bone remodeling," Cell Death and Differentiation, vol. 16, no. 10, pp. 1332-1343, 2009.

[49] J. Ding, O. Ghali, P. Lencel et al., "TNF-alpha and IL-1beta inhibit RUNX2 and collagen expression but increase alkaline phosphatase activity and mineralization in human mesenchymal stem cells," Life Sciences, vol. 84, no. 15-16, pp. 499-504, 2009.

[50] L. Zhao, J. Huang, H. Zhang et al., "Tumor necrosis factor inhibits mesenchymal stem cell differentiation into osteoblasts via the ubiquitin E3 ligase Wwp1," Stem Cells, vol. 29, no. 10, pp. 1601-1610, 2011.

[51] H. L. Lee, T. Yi, K. Baek et al., "Tumor necrosis factor-alpha enhances the transcription of Smad ubiquitination regulatory factor 1 in an activating protein-1- and Runx2-dependent manner," Journal of Cellular Physiology, vol. 228, no. 5, pp. 1076-1086, 2013.

[52] H. H. Cho, K. K. Shin, Y. J. Kim et al., "NF-kappaB activation stimulates osteogenic differentiation of mesenchymal stem cells derived from human adipose tissue by increasing TAZ expression," Journal of Cellular Physiology, vol. 223, no. 1, pp. 168-177, 2010.

[53] K. Hess, A. Ushmorov, J. Fiedler, R. E. Brenner, and T. Wirth, "TNFalpha promotes osteogenic differentiation of human mesenchymal stem cells by triggering the NF-kappaB signaling pathway," Bone, vol. 45, no. 2, pp. 367-376, 2009.

[54] G. E. Glass, J. K. Chan, A. Freidin, M. Feldmann, N. J. Horwood, and J. Nanchahal, "TNF-alpha promotes fracture repair by augmenting the recruitment and differentiation of muscle-derived stromal cells," Proceedings of the National Academy of Sciences of the United States of America, vol. 108, no. 4, pp. 1585-1590, 2011.

[55] B. Osta, G. Benedetti, and P. Miossec, "Classical and paradoxical effects of TNF-alpha on bone homeostasis," Frontiers in Immunology, vol. 5, p. 48, 2014.

[56] G. Chen, C. Deng, and Y. P. Li, "TGF-beta and BMP signaling in osteoblast differentiation and bone formation," International Journal of Biological Sciences, vol. 8, no. 2, pp. 272-288, 2012.
[57] P. ten Dijke, "Bone morphogenetic protein signal transduction in bone," Current Medical Research and Opinion, vol. 22, Supplement 1, pp. S7-11, 2006.

[58] V. Rosen, "BMP2 signaling in bone development and repair," Cytokine \& Growth Factor Reviews, vol. 20, no. 5-6, pp. 475-480, 2009.

[59] M. Yamazaki, H. Fukushima, M. Shin et al., "Tumor necrosis factor alpha represses bone morphogenetic protein (BMP) signaling by interfering with the DNA binding of Smads through the activation of NF-kappaB," The Journal of Biological Chemistry, vol. 284, no. 51, pp. 35987-35995, 2009.

[60] R. L. Huang, Y. Yuan, J. Tu, G. M. Zou, and Q. Li, “Opposing TNF-alpha/IL-1beta- and BMP-2-activated MAPK signaling pathways converge on Runx2 to regulate BMP-2-induced osteoblastic differentiation," Cell Death \& Disease, vol. 5, article e1187, 2014. 


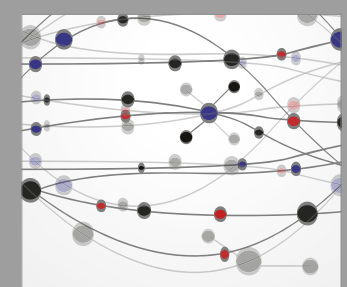

The Scientific World Journal
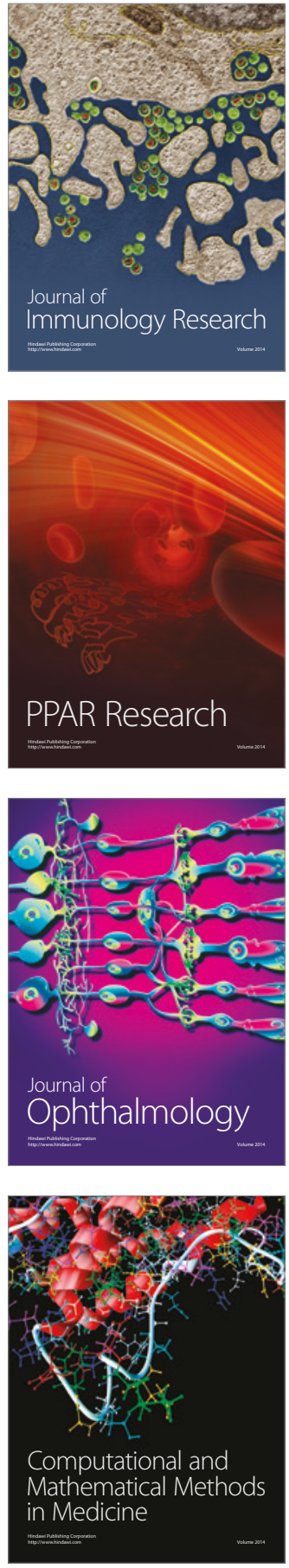

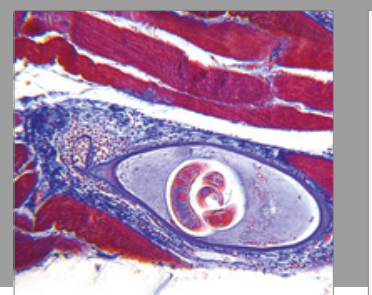

Gastroenterology Research and Practice
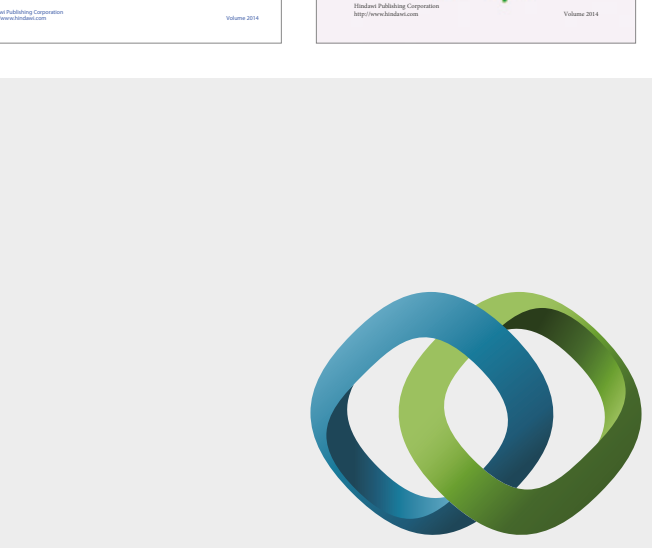

\section{Hindawi}

Submit your manuscripts at

https://www.hindawi.com
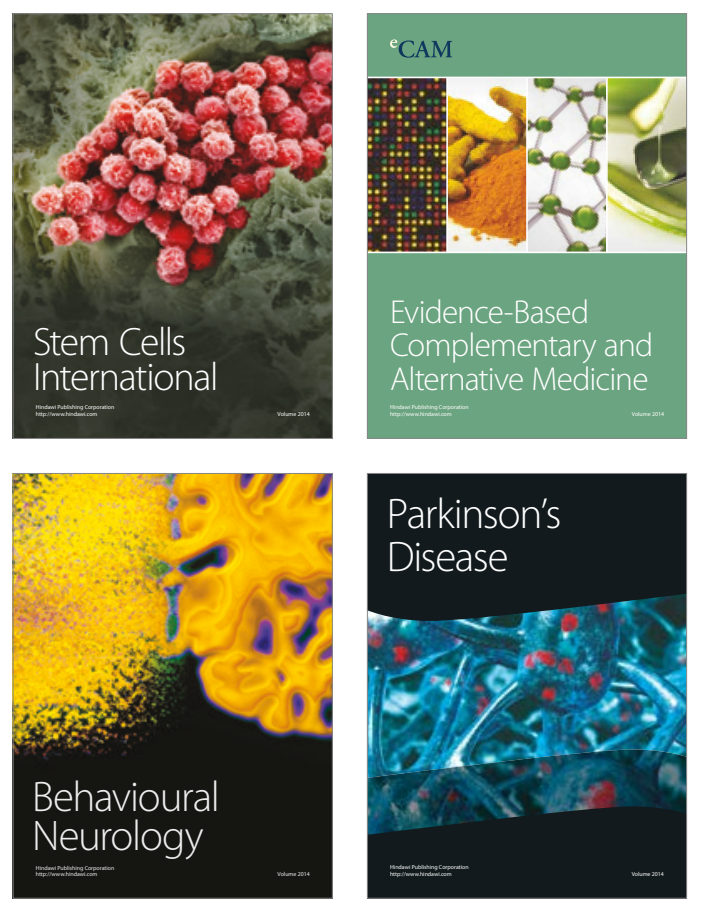
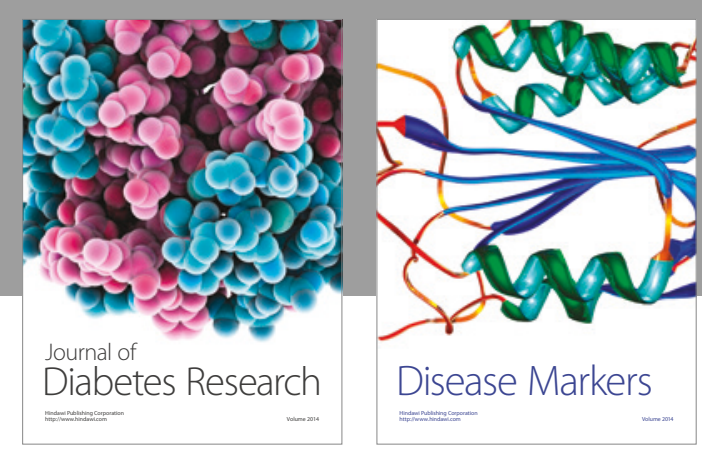

Disease Markers
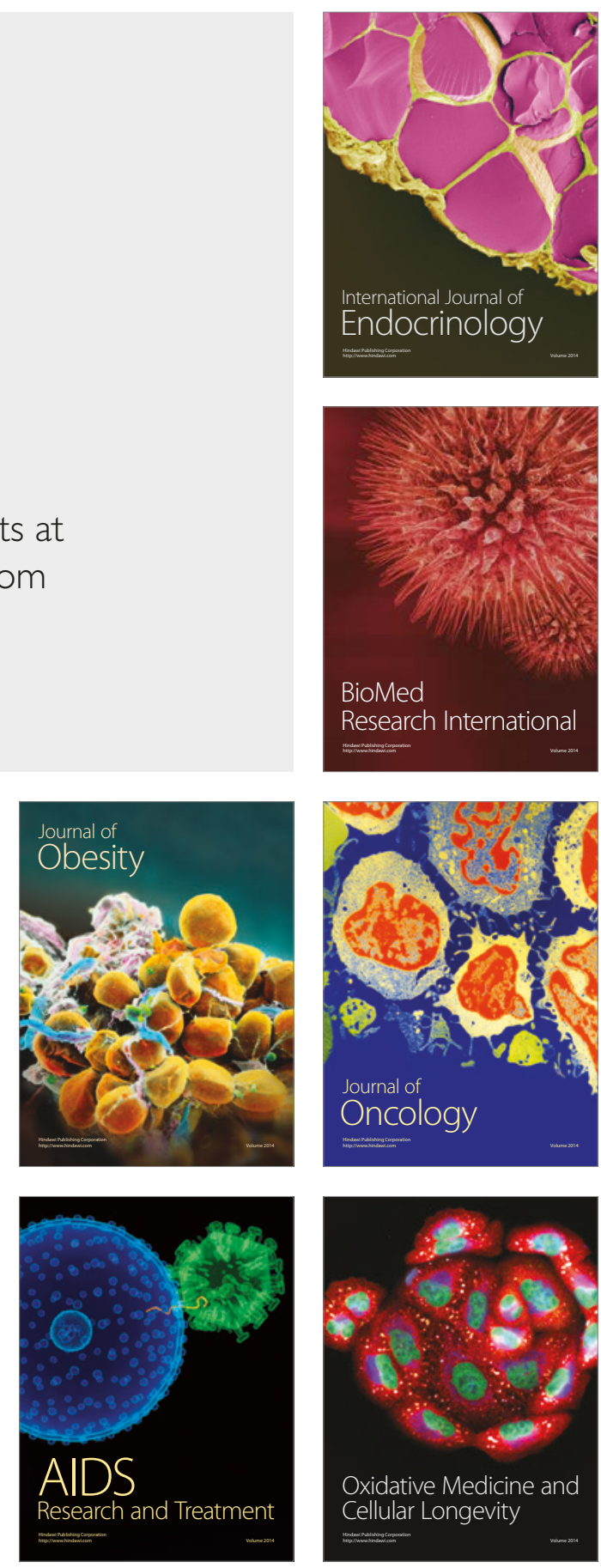